Ministerstwo Nauki

i Szkolnictwa Wyższego

Digitalizacja archiwalnych numerów czasopisma naukowego Analecta Cracoviensia 1-24 (1969-1992)

i ich publikacja w otwartym dostępie - zadanie finansowane w ramach umowy 672/P-DUN/2017 ze środków

Ministra Nauki i Szkolnictwa Wyższego przeznaczonych na działalność upowszechniającą naukę

Ks. EDMUND MORAWIEC

\title{
O METAFIZYCE ZACHOWAWCZEGO TOMIZMU
}

Współczesny tomizm, to właśnie ten, który zaczął się rozwijać po wydaniu w 1879 roku Encykliki Aeterni Patris przez papieża Leona XIII, w której papież zachęca do studiowania filozofii Tomasza z Akwinu we wszystkich kościelnych instytutach naukowych. Od chwili wydania tego dokumentu filozofia Tomasza $\mathrm{z}$ Akwinu oraz związane $\mathrm{z}$ nią interpretacje, które zachowały się do czasu wydania wspomnianej Encykliki, po długiej przerwie poddane zostały intensywnym badaniom. Mówi się tu ,po dlugiej przerwie”, ponieważ w wieku XIV, XV a nawet XVI filozofia św. Tomasza nie miała wielkiego wpływu na kształtowanie się kultury filozoficznej w Europie. Tak zwani tomiści, którzy następowali po sobie począwszy od drugiej połowy XIV wieku w zasadzie ograniczali się do powtarzania i komentowania tego, co napisali ich mistrzowie, zamykając się na odkrycia $\mathrm{w}$ dziedzinie filozofii ${ }^{1}$. Na taki stan rzeczy złożyły się z jednej strony potępienie niektórych tez Tomaszowych przez administrację kościelną, z drugiej zaś nieco później, silny rozwój myśli zapoczątkowanej przez empiryczną szkołę w Chartres i Oksfordzie. W wieku XVII filozofia Kartezjusza, Galileusza, Malebrancha i Pascala wypierają znaną wówças suarezjańską wersją tomizmu z szeroko pojętej filozofii chrzeș́cijańskiej. Filozoficzna problematyka tego nurtu podejmowana jest wówczas na gruncie filozofii pozascholastycznej. Również $\mathrm{w}$ wieku XVIII i w początkach XIX filozofia Tomasza nie zyskała sobie wielkiego znaczenia. Ciągle jeszcze jej wykład ograniczał się do komentowania dzieł św. Tomasza. Fakt ten miał jednak przynajmniej to znaczenie, że filozofia ta przetrwała czasy Renesansu i Oświecenia i w XIX i XX wieku nastąpiło jej odnowienie pod wpływem wspomnianej wyżej Encykliki. Od momentu ukazania się Encykliki Aeterni Pat-

1 Sciślej mówiąc w wieku XVI i XVII następuje pewne ożywienie w dziedzinie filozofii tomistycznej. Widać to szczególnie w szkole dominikańskiej w Salamance i jezuickiej szkole w Coimbrze. W tej ostatniej zasłynął, dzięki swej erudycji i płodności pisarskiej, Fr. Suarez; Zob. P. Chojnacki Filozofia tomistyczna i neotomistyczna, Poznań 1947, s. 91; Por. W. Granat, O nowe spojrzenie na tomizm, w: Znak 3 (1948) nr 7/14, s. 606-609; Por. bp M. Klepacz, Sw. Tomasz na tle dziejów myśli ludzkiej, w: Znak 3 (1948) $\mathrm{nr} 3$ (10) s. 193-221. 
ris omawiany kierunek filozofii zwykło się określać mianem neoscholastyki, lub mianem neotomizmu. Neotomizm więc to współczesny tomizm, stanowiący aktualnie jeden z głównych nurtów filozofii chrześcijańskiej XX stulecia. Rozwija się on obok innych nurtów tej filozofii, takich jak: neoskotyzm, neosuarezjanizm, a nawet można mówić o neobonawenturianizmie.

Po ukazaniu się Encykliki Aeterni Patris tomizm zaczął odradzać się $\mathrm{w}$ trzech zasadniczych kierunkach: tradycyjnym, który nazywa się wersją zachowawczą, współczesnym, który określa się wersją otwartą oraz w kierunku precyzującym, który nazywa się wersją tomizmu precyzującego ${ }^{2}$. Podział ten, co trzeba zaznaczyć, nie jest podziałem rozłącznym. Wspomniane wersje zawierają przecież wspólne i bliskoznaczne rozstrzygnięcia, dotyczące podstawowych niekiedy zagadnień występujących $\mathrm{w}$ filozofii Tomasza $\mathrm{z}$ Akwinu. Ale zauważa się $\mathrm{w}$ nich także pewne różnice, zwłaszcza w zakresie sposobu podejścia do zagadnień filozoficznych, tak w etapie początkowym jak i końcowym.

$\mathrm{W}$ artykule niniejszym przedmiotem rozważań stanie się metafizyka pierwszej z wymienionych wersji tomizmu jako nurtu filozofii klasycznej. Zwróci się tu uwagę na trzy uzupełniające się wzajemnie zagadnienia: esencjalizm będący podstawową własnością tej wersji tomizmu, niektóre jego historyczne źródła oraz źródła merytoryczne. Te ostatnie stanowić będą pewne rozstrzygnięcia z zakresu samej interpretacji koncepcji struktury bytu. Podjęcie takiego zagadnienia może przyczynić się do głębszego zrozumienia klasycznej koncepcji metafizyki nurtu realistycznego ujawniającej się w tzw. tomizmie zachowawczym.

\section{A. ESENCJALIZM JAKO PODSTAWOWA WEASNOSC METAFIZYKI TOMIZMU ZACHOWAWCZEGO}

Charakterystyczną cechą tomizmu w jego wersji zachowawczej jest to, że właściwa mu metafizyka, jako podstawowa dyscyplina filozoficzna, ma charakter esencjalistyczny, to znaczy, najkrócej mówiąc, jest teorią bytu, wyjaśniającą go jedynie w aspekcie istotowym, pomijając właściwy bytowi aspekt istnieniowy. Znaczyłoby to, że przedstawiciele tego nurtu tomizmu nie dostrzegali zasadniczej różnicy, która istniała i istnieje między metafizyką Tomasza z Akwinu a metafizyką Arystotelesa. Pod tym względem zauważa się też wśród przedstawicieli zachowawczego nurtu tomizmu tendencje, zmierzające do utrzymania u-

2 Por. M. Gogacz, Wspótczesne interpretacje tomizmu, w: Znak 15 (1963) nr 113 (11) s. 1339-1353; Por. Aktualne dyskusje wokót tomizmu, ZN KUL X (1967) z. 3, s. $59-70$. 
trwalonych $\mathrm{w}$ wiekach średnich przekonań, iż myśl filozoficzna Tomasza z Akwinu nie odbiega zasadniczo od filozoficznej myśli Arystotelesa. Zauważa się tė̇ tendencję utrwalającą przekonanie, że interpretacja myśli Tomasza z Akwinu, oczywiście, myśli filozoficznej, jaka pojawiła się w średniowieczu, oddaje w sposób autentyczny całą rzeczywistość filozofii tego średniowiecznego myśliciela. Być może tendencje te miały wpływ na charakter interpretacji metafizyki Tomasza z Akwinu, niemniej trzeba sobie uświadomić, że przypisujący Tomaszowi z Akwinu uprawianie metafizyki na wzór arystotelesowski, bynajmniej nie sądzili, że Tomasz z Akwinu nie wprowadził w swój sposób rozumienia metafizyki daleko idących zmian. Owszem, przyznawali wprowadzenie takich, lecz nie tak dalece, aby - jak okazuje się - mogły jego metafizykę ustrzec przed właściwym jej esencjalizmem.

Jak dobrze wiadomo, esencjalistyczny charakter metafizyki w ujęciu klasycznym ostatecznie warunkowany jest samą koncepcją jej przedmiotu i to przedmiotu formalnego. Gdy zaś chodzi o ten rodzaj przedmiotu, co warto przypomnieć, że ustalenie jego, bliższe określenie jego natury, nie jest niezależne od tego, co rozumie się przez sam byt, od tego, co rozumie się przez ten czynnik, który ostatecznie rozstrzyga o bytowości każdego dystrybutywnie branego bytu. Uformowanie się takiego pojęcia bytu będzie miało w tym przypadku zasadnicze znaczenie. Metafizyka klasyczna bowiem rozpatruje każdy byt, dystrybutywnie brany w aspekcie jego ostatecznych bytowych uwarunkowań, co właśnie wyraża się w formie językowej: „metafizyka zajmuje się bytem jako bytem”. Jeśli powiedziano tu, że pojęcie bytu, w którym mieści się zrozumienie jego natury, jest dla metafizyki istotne, to uczyniono tak dlatego, że ma się przekonanie, iż pojęcie to poprzez wyznaczenie metafizyce właściwego przedmiotu wpływa na wyznaczenie charakteru i kierunku metafizycznych badań. Trzeba jednak pamiętać, że do takiego pojęcia bytu można dojść pod warunkiem, iż zastosuje się procesy poznawcze zdolne odsłonić samą strukturę bytu. Bez poznania struktury bytu nie sposób urobić sobie pojęcie bytu, które ujmowałoby adekwatnie samą naturę bytu.

Tego, co powiedziano wyżej o przedmiocie formalnym metafizyki i jego stosunku do cechy esencjalizmu w metafizyce doskonale sprawdza się w metafizyce arystotelesowskiej. Metafizyka bowiem Arystotelesa jest esencjalistyczna $\mathrm{w}$ znaczeniu podanym wyżej. Jej esencjalizm wyznaczony jest właśnie samym jej przedmiotem formalnym, a przedmiot ten $\mathrm{z}$ kolei wyznaczony jest sposobem rozumienia samego bytu. Według bowiem Arystotelesa, metafizyka brana jako ,filozofia pierwsza" stanowi poznanie ogólne, którego przedmiotem jest byt jako byt i wszystko, co z tym bytem istotnie się łączy. Oto jeden spośród tekstów ilustrujących samą koncepcję metafizyki: „nie utożsamia się ona $\mathrm{z}$ żadną $\mathrm{z}$ 
tak zwanych nauk szczegółowych, bo żadna inna poza nią nie rozpatruje w ogólności bytu jako bytu, lecz wyodrębniając jakąś jego dziedzinę, rozważa to, co mu przysługuje $\mathrm{w}$ tym zakresie... Skoro też szukamy i przyczyn ostatecznych, jasne że muszą to być zasady... rzeczywistości jako takiej” ". Bliższa analiza kontekstu pokazuje, że termin „byt jako byt" w nomenklaturze filozoficznej Arystotelesa oznacza substancję, ale substancję ukonstytuowaną przez konkretną formę, o ile ta jest podstawą dla ujęć poznawczych wyrażonych w realnych definicjach. Tak pojętą substancję można określić nazwą ,substancjalność". To, co zawiera treść tej nazwy ostatecznie rozstrzyga o bytowości każdego bytu, czyli każdej konkretnej substancji. Pojęcie takiej substancjalności uzyskuje się w drodze poznania abstrakcyjnego. Substancjalność tak pojęta stanowi to, co można nazwać przedmiotem formalnym poznania metafizykalnego i jako taka będzie ontyczną podstawą dla konieczności jego twierdzeń. Metafizyka Arystotelesa będzie więc rozpatrywać konkretne substancje lecz zawsze w aspekcie ich substancjalności, czyli treści konstytuujących ich bytowość.

Taka koncepcja przedmiotu formalnego metafizyki podyktowana została u Arystotelesa koncepcją samego bytu i jego struktury. Jak bowiem wiadomo struktura substancji sprowadza się do złożenia dwu elementów materii i formy substancjalnej, gdzie forma pełni funkcję czynnika wyznaczającego samą bytowość rzeczy. Byt w tej koncepcji jawi się jako istota, w której złożenie z materii i formy, z treści gatunkowych i jednostkujących uzasadnia realność rzeczy. Jak się powszechnie podkreśla Arystoteles nie odróżniał treściowego i egzystencjalnego aspektu konkretnego bytu. Nie czuł potrzeby wyróżnienia takiego elementu odrębnego od materii i formy, który uzasadniałby byt po linii jego istnienia. Tę funkcję według Arystotelesa spełnia forma substancjalna, ona też pod każdym względem była podstawą tego, co Arystoteles nazywał substancjalnością bytu, a co stanowiło przedmiot formalny tzw. „filozofii pierwsz€ j'š Taką właśnie postawę w metafizyce nazywa się esencjalizmem.

Esencjalizm jest więc pewną właściwością metafizyki, która jak okazuje się bezpośrednio tkwi w samej koncepcji bytu. W filozofii klasycznej esencjalizm występuje w różnych formach i w różnym natężeniu. Zawsze jednak zauważa się go tam, gdzie w strukturze bytu wyklucza się istnienie jako element składowy bytu oraz tam, gdzie wprawdzie przyjmuje się istnienie, lecz jego rolę w bycie sprowadza się do czegoś przypadłościowego w stosunku do samej istoty bytu, najczęściej do uobecniania lub uaktualniania treści będącej skądinąd bytem. O esencja-

3 Por. Arystoteles, Metafizyka, K. 3 1060b. 31; Por. także M. A. Krąpiec, Analogia bytu, Lublin 1959, s. $61-71$. 
listycznej metafizyce można także mówić w przypadkach, w których przyjmuje się jedynie różnicę myślną między istotą a istnieniem w bytach. Przykładem esencjalizmu w pierwszym znaczeniu, gdzie w ogóle nie pomijało się istnienia $w$ opisie bytu jest właśnie esencjalizm właściwy metafizyce Arystotelesa, przykładem zaś esencjalizmu, podstawą którego była interpretacja istnienia jako przypadłości, jest metafizyka Awicenny i wszystkie inne na niej zbudowane. Suarezjańska metafizyka prezentuje ostatni typ esencjalizmu. Można też mówić o esencjalizmie i tam, gdzie wprawdzie przyjmuje się istnienie jako element konstytutywny bytu, a relację w stosunku do istoty określa się przy pomocy pojęcia róźnicy realnej, jednak nie interpretuje się, czy też nie akcentuje się w sposób właściwy jej roli, jaką ona pełni, jeśli chodzi o samą — tak można się wyrazić — bytowość bytu.

Gdy mowa o esencjalizmie metafizyki tomizmu zachowawczego, trzeba podkreślić jego niejednolitość. Wspólne dla niego wydaje się być założenie, iż tym co w bycie pojmuje się najpierw i co ostatecznie stanowi pierwsze źródło wszelkich jego właściwości i działań jest określony zestaw cech, zwany istotą. Istota rozumiana jest tu jako układ elementów niesprzecznych ze sobą i jako taki nacechowany już jest pewnym stopniem realności. Nie istnienie rozstrzyga tu o „bytowości” bytu, chociaż akceptuje się go, lecz istota. Przeglądając ukształtowane wykłady metafizyki tomistycznej takich przedstawicieli zachowawczego tomizmu, jak np. G. M. Manser ${ }^{4}$, P. Descoqs ${ }^{5}$, A. Forest ${ }^{6}$, J. Gredt ${ }^{7}$ a u nas w Polsce S. Adamczyk ${ }^{8}$ czy P. Chojnacki ${ }^{9}$ nie trudno zauważyć, że najbliższą racją uzasadniającą esencjalizm ich metafizyk jest przyznawanie istocie jako elementowi składowemu bytu ontycznego pierwszeństwa $w$ konstytuowaniu bytu. Każdy $\mathrm{z}$ nich metafizyczną myśl Tomasza $z$ Akwinu interpretuje $w$ duchu esencjalizmu, chociaż nie każdy korzysta $\mathrm{z}$ jednych i tych samych źródeł historycznych. Jak wiadomo P. Descoqs metafizyczną myśl Tomasza z Akwinu rozwija w duchu suarezjańskim, natomiast $\mathrm{A}$. Forest $\mathrm{w}$ duchu eçriejalizmu kartezjańskiego. J. Gredt i S. Adamczyk, mieszając w swej metafizyce porządek możnościowy z możliwościowym, zdają się być bliżej tradycji wolffiańskiej, niż autentycznej scholastycznej tradycji tomistycznej, nawiązującej ${ }^{*} w$ pewnych przypadkach do arystotelizmu. Obaj mieszają porządek epistemologiczny z porządkiem metafizycznym. Metafizyka np. dla J. Gred-

${ }^{4}$ Por. Das Wessen des Thomismus, 3 wyd. Freiburg Schw. 1949.

5 Por. Institutiones, methaphysicae, generalis, Paris 1925.

${ }^{6}$ P.or. La structure metaphysique du concert selon saint Thomas, Paris 1931.

7 Elementa Philosophiae, t. II Barcelona 1951.

$\&$ Metafizyka ogólna, Lublin 1960.

9 Podstawy filozofii chrześcijańskiej, Warszawa 1955, Filozofia tomistyczna $i$ neotomistyczna, Poznań 1947. 
ta, to wiedza utworzona na najwyższym stopniu abstrakcji i dotyczy bytu całkowicie niematerialnego. Formuła językowa: „byt jako byt” oznacza tyle samo, co łacińska formuła ens commune, a więc pojęcie, a ściślej mówiąc abstrakt, stanowiący treści pojęcia ${ }^{10}$. Zresztą z każdej z metafizyk, w której w konstytuowaniu bytowości bytu przekłada się rolę czynnika treściowego nad czynnik istnieniowy, niezależnie od tego, jakie względy za tym przemawiają, termin ,byt jako byt” może tylko oznaczać najbardziej abstrakcyjną treść. Jeșt to konsekwencja z jednej strony stosowania abstrakcji przy formowaniu się tej treści, $z$ drugiej zaś, samego przedmiotu abstrakcji, czyli tego, do czego się ona odnosi, który to przedmiot stanowią istoty rzeczy tak lub inaczej ujęte. Podkreślenie ontycznego pierwszeństwa istoty w konstytuowaniu bytu nie przekreśla w tych ujęciach metafizyki akceptacji istnienia jako elementu strukturalnego bytu. W tym punkcie metafizyki te odbiegały w interpretacji filozofii Tomasza z Akwinu od linii arystotelesowskiej. Niemniej zbliżały się do niego, akcentując istotną rolę czynnika treściowego, przy równoczesnym przyjmowaniu istnienia jako realnie różnego od istoty $\mathrm{w}$ konstytuowaniu bytu, czego nie ma u Arystotelesa. Pod tym względem metafizyki te przypominają czysty arystotelizm. Wydaje się, iż jedną z podstawowych przyczyn takiego stanu rzeczy były źródła zastane przez przedstawicieli tomizmu zachowawczego, w których wyłożona była podstawowa doktryna filozoficzna Tomasza z Akwinu i to zasadniczo w duchu esencjalizmu. Oto kilka uwag o źródłach tych w aspekcie ich stosunku do autentycznej myśli filozoficznej Tomasza z Akwinu.

\section{B. ŹRÓDEA HISTORYCZNE ESENCJALNEJ INTERPRETACJI METAFIZYKI TOMASZA Z AKWINU}

Do źródeł odradzającego się tomizmu w drugiej połowie XIX wieku i w wieku XX zalicza się szesnastowieczne komentarze Tomasza Kajetana de Vio oraz Sylwestra z Ferrary ${ }^{11}$, jak również pewne recepcje filozofii Tomasza z Akwinu wśród których najbardziej rozpowszechnione były: recepcja Fr. Suareza oraz recepcja Chr. Wolffa, pochodzące z XVII w.

W komentarzach Kajetana de Vio interpretacja koncepcji bytu Tomasza z Akwinu zasadniczo odbiega od koncepcji bytu pozostawionej przez Arystotelesa ${ }^{12}$. Kajetan de Vio wyraźnie bowiem odróżnia w struk-

10 Por. Elementa philosophiae t. II, s. 4-10.

11 Por. Caietanum Thomas de Vio, Commentaria in Summam theologiam, ed. Leonina t. IV-XII, Roma 1888-1906.

12 Por. Kajetan, Commentaria in praedicamenta Aristotelis, wyd. Laurent, Roma 
turze bytu element istotowy $\mathrm{i}$ istnieniowy, co znajduje także wyraz w samym pojęciu bytu. Pojęcie to (o ile mona tak powiedzieć), syntetyzuje byt wzięty esencjalnie i egzystencjalnie. Niemniej rola istnienia w bycie ograniczana jest do funkcji aktualizacji istoty, rozumianej jako zespół cech determinujących byt. Aktualizacja ta, według Kajetana de Vio, dokonuje się $w$ ten sposób, że istnienie aktualizując istotę nie wpływa przez to samo na treść bytu, inaczej mówiąc, nie wpływa na kategorialność bytu. Przynależy ono do istoty o tyle, o ile ją aktualizuje, nie zmieniając przy tym nic z jej treści, ani też nie dodając do niej żadnych nowych właściwości, jako zaktualizowanej. Tak więc pojęcie bytu należy rozumieć jako istotę $\mathrm{w}$ relacji do istnienia, albo też istnienie zdeterminowane przez istotę. Jak podkreśla Krąpiec pojęcie bytu według Kajetana de Vio, jest wspólne wszystkim istotom, ale nie rozróżnia ich między sobą i dlatego też pojęcie to nie mieści się w definicji rzeczy. Definicja bowiem zawiera tylko to, co odróżnia jedne rzeczy od innych, nie zawiera więc składników wspólnych wszystkim rzeczom ${ }^{13}$. Jak widać z powyższego Kajetan de Vio rozumie byt również jako istotę, która przeniknięta jest istnieniem. To istnienie jest dla istoty czymś zewnętrznym, z czym istota nie utożsamia się, lecz w czym partycypuje.

Tak więc, chociaż Kajetan de Vio pojęcie bytu jako bytu przejął zasadniczo od św. Tomasza, to zbyt sztucznie i radykalnie przeciwstawił istotowy aspekt aspektowi istnieniowemu, akcentując istotową stronę bytu. I chociaż bytem rzeczywistym jest tylko byt pojęty egzystencjalnie, o czym może świadczyć następujący tekst: dico énim quod ens participaliter est in quod est transcendens, diversum in decem praedicamenta, to jednak istota posiada w sobie czynniki determinujące, ostatecznie wykańczające bytowość, a istnienie tylko aktualizuje wykończoną w sobie i zrozumiałą w sobie bytowość. Istnienie jest tylko orzeczeniem przypadłościowym. W bytach przygodnych o tyle przynależy do istoty, o ile ją aktualizuje nie zmieniając przez to żadnej kategorii, ani nie dodając żadnych nowych cech do istoty ${ }^{14}$.

Nieco inaczej do problemu bytu podchodzi Sylwester z Ferrary w swych komentarzach do Summy filozoficznej. Jak zauważa A. Krąpiec, dokonuje on pewnych poprawek kajetanowskich interpretacji Tomaszowej koncepcji bytu. Przyjmując rozróżnienie w bycie na istotę i istnienie, Sylwester z Ferrary prezentuje nam pojęcie bytu zawierające w sobie zdwojenie $z$ elementu esencjalnego i egzystencjalnego. Pojęcie to stanowi jedność tych elementów, tak że nie można pomijać jednego $z$

1939, s. 20; Por. także M. A. Krąpiec, dz. cyt., s. 74; Por. także A. Marc, L'idee de l'etre chez saint Thomas et dans la scholastique posterieur, Paris 1933, s. 52.

13 Por. M. A. Krąpiec, dz. cyt., s. 74; Por. także M. Gogacz, Wspótczesne interpretacje tomizmu, s. 1347-1348.

14 Por. M. A. Krąpiec, dz. cyt., s. 207. 
nich i zarazem opisywać byt w sposób adekwatny. Między elemeñtami składowymi bytu: istotą $i$ istnieniem zachodzi jedność proporcjonalna ${ }^{15}$.

Porównując dwie powyższe interpretacje, zauważa się, że Kajetan de Vio zbyt zeschematyzował przekazane tradycji filozoficznej pojęcie bytu Tomasza z Akwinu. Tej schematyzacji ustrzegł się właśnie Sylwester z Ferrary i dzięki temu oddał w sposób autentyczny myśl św. Tomasza, dostrzegając $\mathrm{w}$ bycie aktualnie istniejącym przedmiot badania metafizyki. Osiągnięcia w zakresie interpretacji bytu Sylwestra z Ferrary nie miały jednak większego znaczenia dla przyszłego tomizmu. W ciągu dalszych wieków zapanowała prawie całkowicie teoria Kajetana i to $w$ dodatku tak dalece, że Ramirez mógł napisać, iż nie są mu znani inni wybitniejsi tomiści, którzy by znali koncepcję Sylwestra z Fer-. rary ${ }^{16}$.

Drugim źródłem dla neotomizmu zachowawczego były - jak wspomniano już wyżej - szesnastowieczne recepcje tomizmu, zachowane w przeróżnych wykładach filozofii Tomasza z Akwinu w takich uniwersytetach jak: Salamanca, Alcala, Koombra, Lipsk, Rostok i Rzym. Liczący się wówczas tomiści to: Franciszek de Vittoria, Kardynał Ximenes, Dominik de Soto oraz Dominik Ramirez. Nieco później na pierwsze miejsce wybija się Fr. Suarez. Tomizm tych czasów ograniczał się w większości przypadków przede wszystkim do wykładów albo komentarzy do dzieł Arystotelesa i Tomasza z Akwinu. Nie spotyka się w nim zasadniczych zmian treściowych chociaż pewne zmiany daje się zaobserwować $\mathrm{w}$, sposobie przeprowadzania wykładów. W ramach programu modernizacji scholastyki prezentowane zagadnienia filozoficzne wzbogaca się bowiem pozytywnymi badaniami historycznymi. W pewnym stopniu od wyżej wymienionych odbiegł Fr. Suarez. Wprawdzie uważał się zarazem za tomistę i scholastyka, jednak w rzeczywistości był tylko scholastykiem. Stosował bowiem scholastyczną metodę wykładu, zgodnie $z$ duchem scholastyki filozofię traktował w sposób nieautonomiczny, niekiedy metodologicznie pomieszany z religią, wiarą i objawieniem. Zasadniczo filozofia stanowiła dla niego racjonalizację wiary lub religii. Tomistą jednak nie był. Odbiegł bowiem tak dalece od filozofii Tomasza z Akwinu, że na 24 tezy uznane później za wyraźnie tomistyczne, w swojej filozofii uznał jedynie pięć. Przede wszystkim zakwestionował Tomaszową koncepcję bytu w jego strukturze oraz w sposobie tłumaczenia relacji zachodzących między elementami składowymi bytu. Zdecydowanie zakwestionował też między innymi realność różnicy między istotą a istnieniem $\mathrm{w}$ bycie. Zdaniem Suareza takie rozróżnienie

15 Por. tamże, s. $75{ }^{\circ}-78$.

16 Por. J. Ramirez, De analogia secundum doctrinam aristotelico-thomisticam, Madriti 1922, s. 74; Por. także M. A. Krąpiec, dz. cyt., s. 211. 
można robić i sam takiego dokonywał, ale nie uważał, by wspomniane wyżej elementy bytu stanowiły coś realnego. Były one według niego jedynie operacjami umysłowymi, distinctiones rationis. Mówiąc o przedmiocie metafizyki (Obiectum adequatum) wyrazi się, iż stanowi go ,byt realny”. Ale termin „byt realny” w języku Suąreza w tym przypadku nie oznacza bytu konkretnie istniejącego. Oznacza on byt, o ile jest zawarty w rzeczach konkretnie istniejących. Jest to więc treść uzyskana w drodze abstrakcji. I tę treść nazywa Suarez bytem jako bytem. Prezentuje on, jak widać, zdecydowanie esencjalistyczną koncepcję bytu ${ }^{17}$.

Drugą recepcję myśli filozoficznej Tomasza z Akwinu, o swoistym wpływie na kształtowanie się zachowawczej wersji tomizmu stanowiła filozofia Christiana Wolffa. Filozofia ta wprawdzie obok źródeł tomistycznych ma także inne źródła, jak np. filozofię Kartezjusza, Spinozy a nawet Leibniza, to jednak jej trzon tkwi w tradycji filozoficznej orientacji arystotelesowsko-scholastycznej. Zewnętrznym wyrazem wpływu tej ostatniej jest zawarta w filozofii Wolffa koncepcja przedmiotu filozofii, jej metody oraz klasyfikacja jej dyscyplin. Dla Christiana Wolffa świat prezentuje się jako zbiór substancji konkretnych, z których każda ilustruje istotę ujmowaną przez podmiot poznający i mogący w sposób wyraźny być zdefiniowaną. Termin ,istota” oznacza w tej filozofii właściwie to samo, co termin „byt”. Ten ostatni brany jest w znaczeniu tego, co istnieje lub istnieć może. O tym, że coś jest bytem ostatecznie decyduje istota rozumiana zawsze jako zespół cech niesprzecznych. Stąd też filozofia wedlug Christiana Wolffa stanowiła teorię istot, a w pewnym sensie także teorię bytów możliwych. Chr. Wolff bardziej jeszcze radykalizuje moment esencjalistyczny w swojej filozofii niż czynili to inni. Jego koncepcja przedmiotu filozofii sprowadzająca przedmiot do istoty, wyznaczyła w konsekwencji całą metodę filozofowania, którą stanowiła metoda dedukcyjna. Mając bowiem wyraźną wiedzę o istotach rzeczy dającą się wyrazić w definicjach można było dedukować całe ciągi koniecznych sądów. Nadto Chr. Wolff był zdania, że dwie podstawowe zasady: zasada niesprzeczności i zasada racji ostatecznej, nie są zasadami czysto logicznymi, ale są również ontycznymi. Stąd też uważając je za podstawowe w myśleniu dedukcyjnym był przekonany, iż metoda dedukcyjna może być stosowana nie tylko w logice i matematyce czyștej, lecz także do badania realnej rzeczywistości. Struktura tej metody odbiegała w pewnym stopniu od tradycyjnej metody dedukcyjnej, właściwej dla filozofii scholastycznej, a wiernie naśladującej model dedukcji arystotelesowskiej. Wolff był bowiem zdania, że sama metoda dedukcyjna nie wystarcza do zbudowania systemu filozofii. Jej uzupeł-

17 Por. W. Tatarkiewicz, Historia filozofii, Warszawa 1958, t. I, S. 43-47; F. Klimke, Historia filozofii. Kraków 1928, s. 310-318. 
nienie ma stanowić doświadczenie i oparta na nim indukcja. W tym przypadku nawiązał on do niektórych przedstawicieli filozofii z XVII wieku. Z kolei jego podział filozofii przypomina podziały spotykane $\mathrm{W}$ tradycji scholastycznej, kształtowanej pod wpływem filozofii Arystotelesa. Filozofię dzieli na praktyczną i teoretyczną. Filozofia teoretyczna dzieli się na: ontologię zajmującą się bytem jako takim, racjonalną psychologię, ktọ́rej przedmiotem jest ludzka dusza, kosmologię jako naukę o .świecie oraz naturalną teologię, której przedmiot stanowi istnienie j atrybuty Boga. Filozofia praktyczna obejmuje etykę, ekonomię i politykę. Wyraźnie też oddziela metafizykę ogólną, nazywaną często ontologią, od teologii naturalnej. Tę ostatnią właściwość uważa się za oryginalną $w$ jego koncepcji ${ }^{18}$.

Nie jest rzeczą ważną dla nas w tej chwili, co Wolff zaczerpnął z czystej scholastyki, a co z przefiltrowanej przez poprzednie systemy filozoficzne, z których także korzystał. Ważne, że właśnie on jako jeden z głównych przedstawicieli niemieckiego Oświecenia, które w wielu przypadkach negatywnie odnosiło się do filozoficznej tradycji scholastycznej, realizując ogólnoeuropejskie hasła prądu Oświecenia, nawiązał mocno i żywo do metody scholastycznego wykładu i w ten sposób pozwolił przetrwać tej tradycji jeszcze jeden trudny okres. Także dla atrakcyjności tej filozofii istotny był fakt połączenia się w niej osiemnastowiecznego racjonalizmu $\mathrm{z}$ elementem religijnym, umieszczanym zasadniczo wówczas poza dziedziną racjonalności. Racjonalizm właściwy filozofii Chr. Wolffa w dużym stopniu odbiegał od typu racjonalizmu głoszonego przez jego poprzednika, Chr. Thomasiusa, dla którego tradycyjna filozofia łącznie z jej problematyką była uważana za dziedzinę leżącą poza zasięgiem rzetelnej wiedzy. Thomasius uważał, iż jedynymi źródłami wiedzy i zarazem nauki może być tylko doświadczenie i dedukcja. Racjonalizm wprawdzie wskazywał na identyczne źródła odpowiedzialnej wiedzy ludzkiej, to jednak uprawiając w sposób racjonalistyczny filozofię nie ustawiał jej na pozycjach antyreligijnych. Broniąc metafizyki wbrew ówczésnym tendencjom uznawał nadto, iż w ramach filozofii można uprawiać teologię naturalną, której problematyka była wyłącznie religijna, czyniąc zadość racjonalistycznym zasadom wiedzy ${ }^{19}$.

$18 \mathrm{Chr}$. Wolff, Philosophia rationalis sive logica, Lipsiae 1740; Por. także M. Gogacz, dz. cyt., s. 1345-1346.

19 Por. E. Gilson, Tomizm, tłum. J. Rybałta, Warszawa 1947, s. 52-54. 


\section{PODSTAWY ESENCJALIZMU METAFIZYKI I JEJ CHARAKTER}

Jak widać $\mathrm{z}$ powyższego przedstawienia, źródłowa tradycja filozoficzna dla późniejszego zachowawczego tomizmu interpretowała metafizykę Tomasza $\mathrm{z}$ Akwinu $\mathrm{w}$ duchu esencjalistycznym. Wobec tego może rodzić się pytanie, co ostatecznie spowodowało, że myśliciele nawiązujący w koncepcji bytu do myśli filozoficznej Tomasza z Akwinu i wyróżniający za nim $\mathrm{w}$ bycie złożenie $\mathrm{z}$ istoty i istnienia, odżegnujący się w tłumaczeniu relacji między tymi elementami od sugestii podsuwanych przez filozofów arabskich, Awicennę i Aweroesa, jednym słowem, mający wszystkie atuty po temu, aby dostrzec właściwe pole epistemiczne dla metafizyki, pozostali właściwie przy esencjalnej koncepcji metafizyki jako nauki o bycie jako takim. Otóż wydaje się, że główna przyczyna mieści się $\mathrm{w}$ braku dojrzenia właściwej roli istnienia $\mathrm{w}$ bycie. Jak widzieliśmy, rolę tę sprowadzano do aktualizowania bytu. Samo zaś aktualizowanie interpretowano zbyt statycznie, biernie, mało dynamicznie. Wprawdzie przyjmowano, że istnienie jest elementem strukturalnym bytu, że aktualizuje byt, lecz uwaga, iż owa aktualizacja stanowi zarazem konstytuowanie bytu jako bytu, tj. jako czegoś istniejącego, była w tych koncepcjach czymś odległym. Byt konstytuowało nie istnienie lecz istota, lub jak mówiono substancja. Słusznie zauważa M. Gogacz, że jednym $\mathrm{z}$ grzechów esencjalizmu $\mathrm{w}$ uprawianiu metafizyki jest traktowanie istoty istnienia $\mathrm{w}$ bycie zbyt samodzielnie ${ }^{20}$. Istnienie konstytuuje byt, gdyż jest tym między innymi z czego, ex quo, jest byt. Byt jest bytem nie dzięki elementowi esencjalnemu. Dzięki niemu jest tym oto a nie innym bytem. To co sprawia, że w ogóle jest coś bytem, jest istnienie. Tę myśl dobrze chyba wyraził E. Gilson: „W każdym esse habens - esse jest aktem posiadającego je habens, a akt ten ma ten skutek, że to, co go otrzymuje, staje się bytem. Jeśli przyjmiemy mówi dalej E. Gilson - tę tezę w całej rozciągłości, wraz ze wszystkimi implikacjami, stanie się dla nas jasny sens znanega sformułowania św. Tomasza: „,nomen ens imponitur ab ipso esse” ${ }^{21}$. Zarysowuje się tu wyraźnie ontyczne pierwszeństwo istnienia w bycie. Od uznania go lub nie uznania, w takiej lub innej formie, ostatecznie będzie zależał charakter całej filozofii, a szczególnie metafizyki. Nie tyle więc akceptacja złożenia $\mathrm{w}$ bycie istoty $\mathrm{i}$ istnienia, ile raczej interpretacja funkcji istnienia w bycie będzie rozstrzygać o przyszłym charakterze poznania metafizykalnego. Otóż z dużą porcją pewności można twierdzić, że przedstawiciele tej tradycji nie dostrzegli $w$ koncepcji bytu Tomasza $z$ Akwinu roli, jaką on wyznaczył istnieniu $\mathrm{w} \cdot$ konstytuowaniu się bytowości. Do- 
tyczy to Kajetana de Vio, Sylwestra z Ferrary i innych szesnastowiecznych tomistów, nie wyłączając późniejszego Suareza i osiemnastowiecznego Chr. Wolffa.

Przedstawiciele tomizmu zachowawczego, nawiązujący do wyżej przedstawionych interpretacji metafizyki Tomasza z Akwinu i kontynuujący ją $w$ rozbudowanych przez siebie ujęciach całościowych filozofii, tworzyli esencjalną koncepcję metafizyki tomistycznej. W szczegółach różnili się oni między sobą, a o różnicach tych zawsze można się przekonać, poddając analizie teksty ich systemowych opracowań. Wspólne dla nich w tym-zagadnieniu zdaje się być przede wszystkim przeświadczenie, iż elementem konstytutywnym bytu jest określony aspekt treściowy, nazywany niekiedy istotą bytu. Aspektowi temu, zgodnie zresztą $\mathrm{z}$ zastaną przez siebie interpretacją, wyznaczają pierwszeństwo epistemologicznie. Przyjmują, iż $w$ bycie pojętym jako to co istnieje, najpierw ujmuje się istotę. Twierdzą, iż istota rozumiana w sensie pierwotnych cech bytu jest źródłem wszelkich jego właściwości i działań. Uznają $w$ ten sposób pierwszeństwo ontologiczne istoty. Istnienie natomiast oprócz roli uaktualniania nie ma zasadniczo innej funkcji. Zależnie od tego jak dalece $\mathrm{w}$ istotach widziano realność, zacierano także różnicę między porządkiem poznawczym a porządkiem realnym. Wyrażono się tu ,zgodnie z zastaną przez siebie interpretacją", ponieważ wyżej opisana sytuacja charakteryzuje treść tak przytoczonych komentarzy, jak również systemów filozoficznych Chr. Wolffa a nawet Fr. Suareza, jako źródeł, z których przedstawiciele zachowawczego tomizmu czerpali swe myśli. We wszystkich tych przypadkach bytem określało się to, co istnieje aktualnie lub istnieje w możności, co po prostu, może istnieć. Bardzo wyraźnie widać to zwłaszcza w filozofii Chr. Wolffa. Wyrażenie ,realne istnienie $\mathrm{x}-\mathrm{a}$ jest wyrażeniem zawierającym $\mathrm{w}$ swej treści jego aktualne i możnościowe istnienie, jako dwa odrębne sposoby istnienia". U podstaw tych stanowisk istnieje fakt, że istnieniu, które przecież akceptowano $\mathrm{w}$ wielu przypadkach jako element wchodzący $\mathrm{w}$ „,compositum" bytu, wyznaczano fúnkcję jedynie aktualizacji, a nie konstytucji bytu.

Do takiego stanowiska $\mathrm{w}$ zakresie koncepcji bytu, tak w przypadku tomizmu zachowawczego, jak też jego źródeł, z których czerpał, przyczynił się fakt korzystania przy jej formułowaniu z tzw. abstrakcji metafizycznej.

O takiej sytuacji w zakresie metafizyki tomizmu zachowawczego świadczy nadto fakt, że u wszystkich jego przedstawicieli abstrakcja wysuwa się na pierwsze miejsce jako operacja poznawcza, w oparciu o którą dochodzi się do formowania pojęcia bytu jako bytu. Abstrakcja ta najczęściej interpretowana jest $\mathrm{w}$ duchu arystotelesowskim. Zbyt moc- 
no bowiem podkreśla się w niej moment negatywny, sprowadzający się do czynności odrywania pewnych części od całości celem lepszego poznania. Oto właśnie w tym procesie poznawczym, który toczy się poprzez znane stopnie, ujmuje się coś, co jest wspólne wszystkim przedmiotom rzeczywistym i możliwym, poddanym kolejnym etapom abstrahowania. Będzie to właśnie treść, która jest nieodłączna od bytu. Wówczas zupełnie jest obojętne, czy w procesie abstrakcji wyszło się od takiego, czy innego przedmiotu. Ważne jest to, do czego się dochodzi, tj. na czym się ostatecznie ów proces zatrzymuje, gdyż to właśnie stanowi ten element, który konstytuuje byt. Jest to element o naturze treściowej; bowiem abstrakcja tak rozumiana nie może do czegoś innego prowadzić, jak tylko do określonego zespołu treściowego. Ten rezultat abstrakcji określa się terminem „,bytowość”. „Bytowość” w esencjalnej koncepcji filozofii charakterystycznej dla tomizmu zachowawczego oznaczając element konstytutywny bytu, oznacza zarazem przedmiot formalny filozofii, a w niej także metafizyki. Zgodnie bowiem z definicją filozofii klasycznej, filozofią nazwać trzeba usystematyzowany zbiór zdań dotyczący rzeczywistości realnej w aspekcie jej bytowości, lub bytu jako bytu, co na jedno wychodzi. Wspólna wszystkim bytom właściwość, czy też ich zespół, składający się na treść pojęcia bytowości, na to, co ostatecznie decyduje, że coś jest bytem w ogóle, a nie tylko tym oto tu, czy też należącym do takiej lub innej kategorii, jest tylko aspektem z punktu widzenia którego rozpatruje się rzeczywistość realnie istniejącą. Nie stanowi ona przedmiotu metafizyki w znaczeniu tego, czego metafizyka dotyczy. Metafizyka esencjalna, charakterystyczna dla tomizmu zachowawczego, nie jest filozoficzną teorią abstraktów, czy filozoficzną teorią pojęć dlatego tylko, że jej przedmiotem właściwym jest uzyskany na drodze abstrakcji, rozstrzygający o bycie, jakiś treściowy jej aspekt ${ }^{22}$. Jest ona filozoficzną teorią realnej rzeczywistości, ponieważ jej przedmiotem materialnym jest realnie istniejąca rzeczywistość, czyli wszystko, co istnieje lub istnieć może. I ta rzeczywistość rozpatrywana jest w aspekcie bytowości. Bytowość ta tkwi w każdym dystrybutywnie branym bycie objętym nazwą ,przedmiot materialny”. Stąd też formuła językowa: „metafizyka bada byt jako byt" w języku esencjalnej metafizyki tomizmu zachowawczego znaczy tyle, że metafizyka rozpatruje rzeczywistość realną, aktualnie lub możliwie istniejącą, w aspekcie bytowości, a nie to, że ten rodzaj metafizyki zajmuje się abstraktami. Tomiści reprezentujący tomizm zachowawczy bardzo wyraźnie podkreślają realny charakter najogólniejszej teorii bytu, jaka jest metafizyka. Swiadczyć mogą o tym jej definicje spotykane w niektórych podręcznikach metafizyki tej wersji tomizmu.

22.Dlatego nie wydaje się słusznym twiendzenie, jakoby metafizyka esencjalna była teorią abstraktów. 
I tak np. według J. Gredta metafizyka jest nauką o bycie jako bycie: scientia entis, ut ens est. Bliższe określenie tej formuły podaje gdy pisze: „Obiectum igitur materiale metaphysicae est quodcumque ens, sicut obiectum materiale physicae est corpus; obiectum autem formale ,quod" est ens ut ens seu, ipsa ratio entis, quam methaphysicus in omnibus entibus considerat, sicut physicus seu philosophus naturalis in omnibus coropribuso considerat rationem mobilitatis sensibilitis" ${ }^{23}$. Podobnie określa metafizykę inny reprezentant zachowawczego tomizmu, Joannes di Napoli. Pisze on: ,eius obiectum (metaphysicae) materiale sunt omnes res quae existunt seu sunt ens. Obiectum formale "quod" est ens inquantum ens, seu ens immateriale, (ens separatum a quacumqua materia)" ${ }^{24}$. Niewiele różni się pogląd w tej sprawie, który głosi F. X. Maquart. Dla niego termin ,byt jako byt” oznacza to samo, co termin „quidditas rei sensibilis ab omni materia abstracta" ${ }^{25}$. Podkreśli jedynie, że pojęcie to nie jest tylko pojęciem uniwersalnym, ale nadto analogicznym. Według tego przedstawiciela zachowawczego tomizmu, „obiectum proprium metaphysicae, est ens scilicet inquantum ens, ope tertii gradus abstractionis formalis obtinetur. Versatur proinde metaphysica powie dalej - circa ens immateriale quidem vi abstractionis materiale tamen quoad existentiam, seu aliis verbis circa idem obiectum materiale ac aliae scientiae, quae sunt de entibus materialibus huiusce modi visibilis" ${ }^{26}$. Takż $\mid$ w koncepcji metafizyki P. P. Descoqsa termin „byt jako byt" oznacza jedynie pewną warstwę bytu realnego, do którego dociera się w drodze poznania umysłowego. Metafizyka według niego to: „Scientia cuiuscumque entis realis qua talis secundum rationes et principia ultima, quae sensum transcendant et necessaria sunt ut illud quodcumque ens id quod et intelligibile fiat". Bliższa analiza tej definicji oraz treści pobliskiego kontekstu wskazuje, że termin ,,cuiuscumque entis realis" oznacza przedmiot materialny metafizyki i odnosi się do bytu, któremu przysługuje istnienie, ale jakiekolwiek, także możliwe, termin zaś „qua talis" oznacza przedmiot formalny i odnosi się do bytu samego w sobie, a więc samej bytowości bytu, bez względu na to, do jakiej kategorii on należy ${ }^{27}$.

Podobnych przykładów można byłoby przytoczyć więcej, ale przecież nie o to chodzi. Podane wyżej ilustracje wystarczająco adekwatnie pokazują esencjalistyczny charakter metafizyki jako najogólniejszej teorii bytu, ale pokazują też, iż mimo ich esencjalizmu, przynajmniej w

\footnotetext{
23 J. Gredt, dz. cyt., t. II, s. $1-2$.

24 Por. Metaphysica generalis, s. 3-4.

25 Por. Elementa philosophiae, Paris t. II, s. 325.

26 Por. tamże, s. 329'.

27 Por. Institutiones metaphysicae generalis, Paris 1925 s. 17.
} 
mniemaniu przedstawicieli tych metafizyk, nie są one pozbawione realistycznego charakteru.

Esencjalistyczne stanowisko w zakresie przedmiotu metafizyki wyznacza charakterystyczny podział filozofii, który zdaje się być dość jednolity u wszystkich przedstawicieli zachowawczego nurtu tomizmu. Filozofię dzieli się tu na metafizykę ogólną, której przedmiotem formalnym jest bytowość bytu, bez względu do jakiej kategorii przynależy. Mówi się tu o bycie w ogólności, bez ułwzględnienia typów bytu. Wyróżnia się następnie metafizykę szczegółową, której przedmiotem materialnym są poszczególne typy bytów, a przedmiotem formalnym aspekt ich bytowości. W tej ostatniej wyróżnia się wiele dyscyplin filozoficznych. Tak więc metafizyka za przedmiot materialny bierze wszystko, co istnieje aktualnie lub możliwie i rozpatruje to w aspekcie bytowości, która stanowi jej przedmiot formalny. Metafizyka zaś szczegółowa zajmuje się roszczególnymi typami bytu, co stanowi jej przedmiot materialny i również rozpatruje w aspekcie bytowości, co z kolei stanowi jej przedmiot formalny. W każdym jednak przypadku odrębności typów bytu aspekt ten wygląda inaczej. W przypadku metafizyki szczegółowej, w tym ujęciu, nie chodzi o istotę bytów należących do klasy określonego typu, lecz o to, aby dany typ bytów rozpatrywać w aspekcie tego, co rozstrzyga o jego bytowości. Tę bytowość nie stanowią, jak mogłoby się wydawać, istoty poszczególnych bytów należących do określonych typów bytu, lecz to co stanowi bytowość, poszczególnych typów bytu. Podstawowym pytaniem zmierzającym do ustalenia przedmiotu formalnego metafizyki szczegółowej jest następujące pytanie: co sprawia, że dany typ bytu jest właśnie danym typem bytu. Jest to pytanie idące po liri esencjalnego porządku określonych typów bytu, dotyczy wprawdzie nie istoty konkretnych bytów, należących do określonego typu bytów, lecz istoty tego samego typu bytów. Taki podział metafizyki odnaleźć można z niewielkimi i nieistotnymi modyfikacjami u każdego z wymienionych przedstawicieli metafizyki esencjalnej zachowawczego tomizmu. Nie trzeba dodatkowo uzasadniać, że z jednej strony, podział ten jest przejrzysty, z drugiej zaś łączy się doskonale $z$ abstrakcjonistyczną koncepcją bytu.

Przedstawiciele omawianej wersji tomizmu nie tylko nie odbiegli daleko od tradycji w interpretacji przedmiotu metafizyki Tomasza z Akwinu, lecz także byli jej bardzo bliscy w poglądach na sam sposób jej uprawiania. We wszystkich cytowanych przypadkach postulują w budowaniu metafizyki metodę dedukcyjną. W pewnych przypadkach jak np. u P. Dezza ${ }^{28}$ i S. Adamczyka ${ }^{29}$ wyraźnie się o tym mówi, w innych

28 Por. P. Dezza, Metaphysica generalis, Roma 1959, s. 11.

29 Por. S. Adamczyk, Metafizyka ogólna, Lublin s. 5. 
zaś na określenie metody omawianej dyscypliny, używa się takich okreŚleń jak: metoda aposterioryczno-aprioryczna lub indukcyjno-dedukcyjcyjna. Sens tych określeń jest taki, na co wskazuje kontekst ${ }^{30}$, że przy dochodzeniu do pojęć i twierdzeń pierwotnych postępuje się analitycznie, indukcyjnie, a posteriori, a przy uzasadnianiu zdań wtórnych i ich systematyzowaniu postępuje się syntetycznile, dedukcyjnie, a priori ${ }^{31}$. Takie poglądy o roli dedukcji w metafizyce, czy w ogóle w filozofii, łączyły się doskonale w myślą Arystotelesa, który w wiedzy występującej $\mathrm{w}$ formie systemu dedukcyjnego widział ideał wiedzy. Trzeba jednak pamiętać, że już wówczas termin „dedukcja” używany na oznaczenie metody wiedzotwórczej nie był jednakowo rozumiany. Określało się nim bądź prziejście myślowe od tego co ogólne do tego, co szczegółowe, bądź proces rozumowania z cechy istotnej, konstytutywnej, o cesze konsekutywnej, bądź rozumowanie oparte na relacji rzeczowej, najczęściej relacji przyczynowości, w którym wyróżniano dedukcję a priori i dedukcję a posteriori, zależnie od tego - czy kierunek rozumowania był zgodny z kierunkiem zależności rzeczowej. Wyżej wymienieni tomiści i cały szereg innych, uprawiających po tej linii metafizykę odbiegało w tym przypadku od intencji Tomasza z Akwinu, który dla metafizyki uważa za właściwe nie postępowanie dedukcyjne, ile raczej modus intelectualis. W komentarzu do De Trinitate Boecjusza wyraźnie stwierdza, że w metafizyce „maxime observatur modus intelectualis" ${ }^{32}$. Niewiele odbiegającą myśl w tej sprawie daje się odnaleźć także u Jana od św. Tomasza. Nawiązując do metody dedukcyjnej, twierdząc, że na jej drodze buduje się metafizykę, w rzeczywistości trudno dopatrzeć się jej w całokształtach różnych prezentacji metafizyki, czy innych dyscyplin filozoficznych, tak w rozumieniu Arystotelesa, a tym więcej w rozumieniu współczesnym. Żadna $\mathrm{z}$ prezentowanych metafizyk nie jest budowana tak, żeby z pewnych zdań przyjętych bez dowodu wszystkie pozostałe dedukcyjnie pośrednio lub bezpośrednio były otrzymywane, względnie do pierwszych sprowadzane. Przy niektórych ujęciach metafizyki wszystkie tezy występujące w niej są dowodzone. Rzeczywiście spotyka się przede wszystkim metodę scholastyczną, w której rozumowanie dedukcyjne stanowi tylko pewien jej fragment. Metoda scholastyczna to nie tylko metoda konstrukcji filozofii, ile raczej jej wykładu i polemiki: methodus doctrince seu dialectica non vero inventionis vel probationis. Ze względu na występu-

${ }^{30}$ Por. L. Raymecner, Metaphysica generalis, Lovanium 1931, s. 11-12; Por. także F. Morandini, Critica, Roma 1959.

31 Por. S. Kamiński, Próba charakterystyki uzasadniania tez $w$ metafizyce klasycznej, w: Z teorii i metodologii metafizyki, Lublin 1962, s. 364.

${ }^{32}$ Por. S. Kamiński, Dedukcja $w$ metafizyce tomistycanej, w: Z teorii i metodologii metafizyki, s. 349 . 
jące w niej rozumowania sylogistyczne, być może całą tę metodę nazywano dedukcyjną. Stąd też pochodzi pogląd, że metoda dedukcyjna jest wystarczającą metodą w uprawianiu metafizyki i w ogóle filozofii.

\title{
A PROPOS DE LA METAPHYSIQUE DU THOMISME TRADITIONALISTE
}

\author{
Rés u m é
}

L'objet des réflexions contenues dans cet article est, ainsi que l'indique le titre, la métaphysique dite du thomisme traditionaliste. Par l'expression „thomisme traditionaliste", on entend ici la philosophie classique, dans son courant réaliste, qui a pris forme dans le cadre du thomisme en train de renaître après qu'eut été publiée, en 1879, l'encyclique Aeterni Patris, par laquelle le pape Léon XIII exhortait à étudier la philosophie de Thomas d'Aquin dans tous les instituts ecclésiastiques supérieurs. Négligée pendant longtemps, la métaphysique classique, dans son courant réaliste, connut une renaissance, justement dans le cadre du thomisme, selon trois directions. La première de ces directions est celle qui se définit par l'appellation de "thomisme traditionaliste”, eu égard au fait qu'on s'y rapporte aux interprérations $\mathrm{du}$ thomisme telles qu'on les reçoit du passé; la deuxième se définit par l'appellation de ,thomisme ouvert" puisque, au sein de ce courant, on pratique la métaphysique classique en essayant de tirer profit aussi bien des sciences particulières que des autres systèmes philosophiques; quant à la troisième direction, elle porte le nom de ,thomisme au sens strict" puisqu'on s'y rapporte à la pensée philosophique authentique de Thomas d'Aquin et non pas, comme c'est le cas dans la première des trois variantes, à diverses interprétations de sa pensée. Soulevant le problème qui est celui de la métaphysique dans le thomisme traditionaliste, l'auteur attire l'attention sur trois questions qui se complètent mutuellement: l'essentialisme comme propiété fondamentale de la métaphysique de cette variante du thomisme, quelques - unes des sources de l'essentialisme ainsi que les caractères propres à la métaphysique elle-même comprise comme l'une des disciplines philosophiques. Dans sa discussion de la question de l'essentialisme dans le thomisme traditionaliste, l'auteur en a fait voir la genèse du contenu en insistant sur le fait que cet essentialisme apparait toujours là où on exclut de la structure de l'être (de l'étant) l'existence comme élément structurel de l'être, et encore là où, tout en admettant l'existence, on réduit celle-ci à une rôle accidentel par rapport à l'essence même de l'être, ou alors là où on ne voit qu'une erreur à distinguer entre ces deux éléments. L'auteur estime également que l'essentialịsme peut même apparaître dans des métaphysiques où l'on reconnaît, dans la conception de l'être, une composition d'essence et d'existence, c'est-à-dire où, par le fait même, on admet qu'il y a à distinguer réellement ces deux éléments, pour autant qu'on n'y explique pas de manière adéquate le rôle de l'existence. Traitant des sources historiques de l'essentialisme de la métaphysique dans le thomisme traditionaliste, l'auteur attire spécialement l'attention sur les interprétations qu'on a données de la philosophie de Thomas d'Aquin à l'époque de la philosophie de la Renaissance ainsi qu'à l'époque des Lumières. Dans la dernière partie de l'article intitulée „Les 
fondements de l'essentialisme de la métaphysique et son caractère" l'auteur passe en revue plusieurs types particuliers d'essentialisme et il examine leur influence sur la métaphysique elle-même, entendue comme une discipline philosophique bien déterminée - tout ceci auprès des plus connus parmi les représentants du thomisme traditionaliste. 